Article

\title{
Slag Substitution as a Cementing Material in Concrete: Mechanical, Physical and Environmental Properties
}

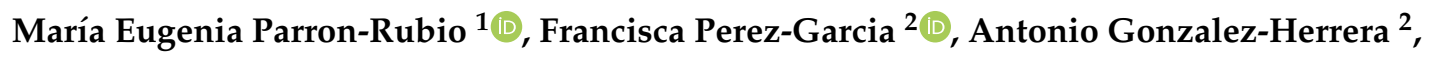 \\ Miguel José Oliveira ${ }^{3}$ (D) and Maria Dolores Rubio-Cintas ${ }^{1, *(D)}$ \\ 1 Departamento de Ingeniería Industrial y Civil, Universidad de Cádiz, 11205 Algeciras, Spain \\ Departamento de Ingeniería Civil, Materiales y Fabricación, Universidad de Málaga, 29071 Málaga, Spain \\ 3 Civil Engineering Department, University of Algarve, 8005-139 Faro, Portugal \\ * Correspondence: mariadolores.rubio@uca.es
}

Received: 17 July 2019; Accepted: 30 August 2019; Published: 4 September 2019

check for updates

\begin{abstract}
A circular economy is a current tenet that must be implemented in the field of construction. That would imply the study of the possibilities of the use of waste generated, for obtaining materials the used in construction as replacements for the raw material used. One of these possibilities is the substitution of the cement by slag, which contributes to the reduction of cement consumption, decreasing $\mathrm{CO}_{2}$ emissions, while solving a waste management problem. In the present paper, different types of concrete made by cement substitution with different type of slags have been studied in order to evaluate the properties of these materials. Cement is replaced by slag from different steel mills, both blast furnace and ladle furnace slag. The percentages of slag substitution by cement are $30 \%$, $40 \%$ and $50 \%$ by weight. Mechanical, physical and environmental properties have been evaluated. Compressive and flexural strength have been analysed as the main mechanical properties. As far as physical properties go, density and porosity tests were be reported and analysed, and from an environmental point of view, a leachate study was performed. It has been found that some kinds of slag (blast furnace slag) are very suitable as substitutes for cement, providing properties above those of the reference concrete, while other types (ladle furnace slag) could be valid for non-structural applications, contributing in both cases to a circular economy.
\end{abstract}

Keywords: concrete; slag; valorisation; cement; circular economy

\section{Introduction}

A circular economy is a currently accepted tenet, in which the traditional linear economy is transformed into a circular economy, where every activity is conceived as a cycle, where waste materials are considered as potential new resources, instead of by-products to discard.

In the field of construction, the challenge is to exploit the possibilities of the waste generated in the building industry as raw materials to be integrated in the same construction cycle.

One of the fields where this strategy is feasible is the incorporation of the slag generated during the steel production into concrete production. It has been used in many processes in the cement production and paving industries. It is interesting to focus attention on this problem and to study, thoroughly, all the possibilities that the steel by-product presents.

The substitution of the cement by slag provides two clear advantages; the first one is the use of a waste that must be managed in a landfill, and the second one, even more relevant, is the reduction in cement consumption, so the reduction of $\mathrm{CO}_{2}$ emissions needed for its production.

Nowadays, there is already a lot of research that supports the adequacy of steel slag for the production of cementitious matrices [1-6]. Additionally, many studies in which aggregates are replaced 
by those types of by-products exist; e.g., blast furnace slag, copper slag, electric arc and fume dust have been used [2,7-16].

There are also some studies on the substitutions of cement by ground granulated blast furnace slag (GGBFS) [5,17-20], even getting up to $80 \%$ of the cement removed by this type of slag. Khatib et al. [21] replaced up to $80 \%$ of cement by GGBFS making different substitutions. Good results were obtained in the substitutions up to $60 \%$, since compressive strengths similar to conventional concrete were obtained. After 28 and 90 days, the strength was increased. Nevertheless, worse results were obtained when replacing $80 \%$ of the slag, and in the first days of setting, the strength of the reference concrete was not reached.

Less attention has been paid to the substitution of cement by ladle furnace slag (LFS). In previous works, different types of slag have been studied and compared, with a maximum amount of $25 \%$ of cement replaced [22]. These studies provided promising results.

In this paper, different types of concrete have been elaborated on, in which the cement is replaced by slag from different steel mills, both blast furnace and ladle furnace slag.

The percentages of slag substitution by cement were $30 \%, 40 \%$ and $50 \%$ by weight. The substitution of cement was made in each mix by types of slag from different factories in Spain. According to different studies, it is known that the component with the highest influence over the durability of cementitious mixtures is $\mathrm{SiO}_{2}$. In this work, we will focus on the relationship between the amount of this component in each slag and the mechanical properties.

Compressive and flexural strength were analysed as the main mechanical properties, making a comparison between all of them to evaluate which one provides the best characteristics.

Additionally, some of the physical and environmental properties evaluated were included in the present paper. For physical properties, density and porosity test were reported and analysed. For a sake of brevity, other tests made are omitted. From an environmental point of view, a leachate study of the material was carried out, since it was essential, considering that waste material was being put into service.

The paper is structured as follows. In Sections 2 and 3, the materials studied and the tests performed have been briefly described. A longer Section 4 is devoted to the results obtained, along with a broad discussion with a special attention to the analysis of the mechanical properties. Finally, conclusions are outlined in Section 5.

\section{Materials}

In this work, a $52.5 \mathrm{R}$ Portland cement (PC) is used; this cement was chosen as it is free of any additives; that is to say, composed of clinker between $95 \%-100 \%$ and between $0 \%-5 \%$ of minor components, without other additives that change their composition. The substitutions were made for the different types of slag that are shown below:

$>$ Slag 1 (GGBFS): Granulated blast furnace slag ground in ball mill.

$>$ Slag 2 (LFS1): Ladle furnace slag (LFS).

$>$ Slag 3 (LFS2): Ladle furnace slag (LFS).

LFS1 and LFS2 are ladle furnace slag with different origins and composition. Slag 1 (GGBFS) has a particle size $<0.063 \mu \mathrm{m}$ provided by the company, while the LFSs were sieved in the laboratory to obtain equal granulometry from them. This is an important fact to keep in mind, since it would be interesting to see what would happen if the LFS slags were also treated in the same way as the GGBFS, but the companies that provided us with that type of slag did not have the technology to do so. Therefore, it was decided to carry out the study with screened slags to study its results.

Three different concrete mixes were designed by substituting $30 \%, 40 \%$ and $50 \%$ of the weight of the cement with slag obtained from three different steel mills in Spain.

The most characteristic chemical values of these slags are shown in Table 1. These values were determined by X-ray fluorescence (XRF). This test was performed with the LFS slags once screened. 
Table 1 shows the major components of the slags studied; the rest of secondary compounds are described in another paper which used the same slags [22].

Table 1. Cement and slag chemical composition.

\begin{tabular}{cccccc}
\hline \multirow{2}{*}{$\begin{array}{c}\text { Cement and Slag } \\
\text { Origin/Chemical Composition }\end{array}$} & $\mathrm{SiO}_{\mathbf{2}}$ & $\mathrm{Al}_{2} \mathrm{O}_{3}$ & $\mathrm{Fe}_{2} \mathrm{O}_{3}$ & $\mathrm{CaO}$ & \multicolumn{1}{c}{$\mathbf{M g O}$} \\
\cline { 2 - 6 } & $\mathbf{\%}$ & $\mathbf{\%}$ & $\mathbf{\%}$ & $\%$ & $\%$ \\
\hline PC & $16.6 \pm 0.5$ & $4.25 \pm 0.5$ & $3.02 \pm 0.02$ & $67.92 \pm 0.5$ & $1.43 \pm 0.05$ \\
\hline GGBFS & $32.3 \pm 0.5$ & $10.7 \pm 0.5$ & $0.29 \pm 0.02$ & $47.14 \pm 0.5$ & $7.64 \pm 0.05$ \\
\hline LFS1 & $13.7 \pm 0.5$ & $9.1 \pm 0.5$ & $1.57 \pm 0.02$ & $55.18 \pm 0.5$ & $16.9 \pm 0.05$ \\
\hline LFS2 & $18.8 \pm 0.5$ & $12.5 \pm 0.5$ & $2.34 \pm 0.02$ & $54.9 \pm 0.5$ & $6.99 \pm 0.05$ \\
\hline
\end{tabular}

The main components $\left(\mathrm{CaO}, \mathrm{SiO}_{2}, \mathrm{Al}_{2} \mathrm{O}_{3}\right)$ of each of the slags are transcribed on a ternary diagram (Figure 1). Observe how the blast furnace slags are those that have better pozzolanic properties, by containing a higher percentage of $\mathrm{SiO}_{2}$.

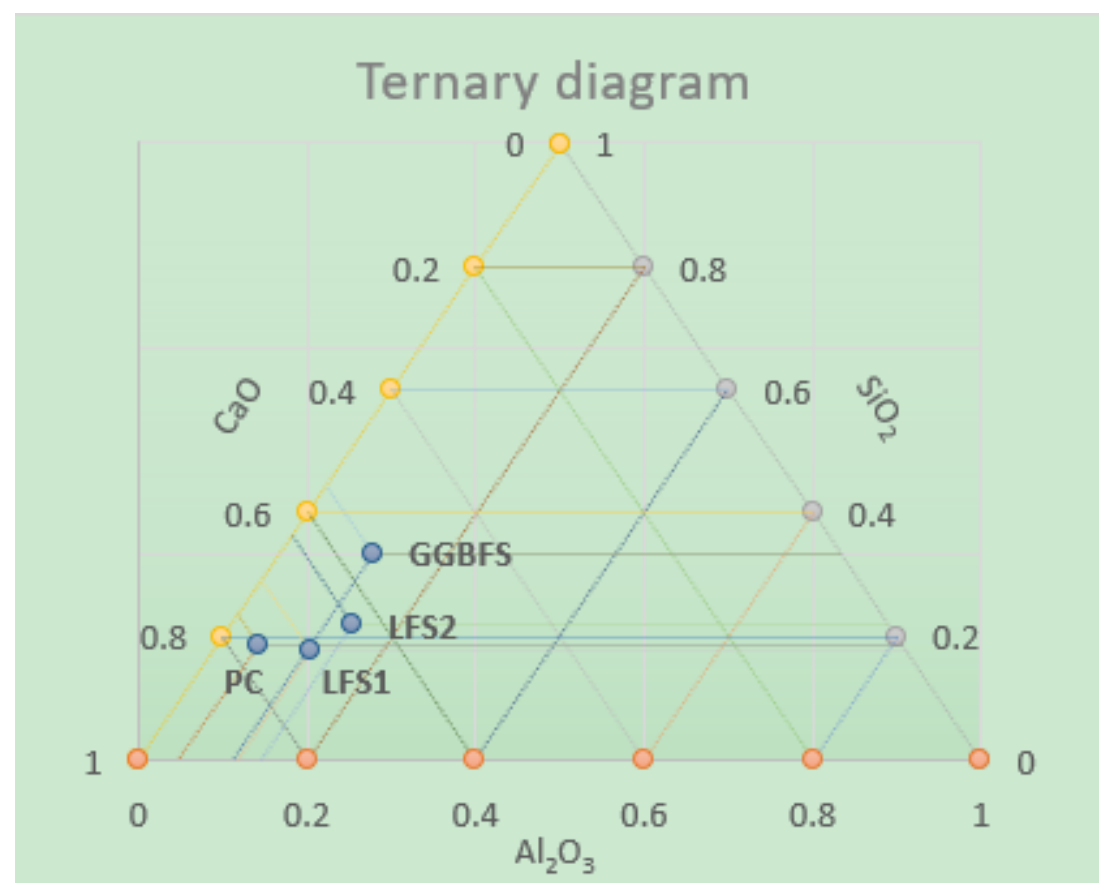

Figure 1. Ternary diagram indicating the compositions of Portland cement (PC), ground granulated blast furnace slag (GGBFS) and ladle furnace slag (LFS) in the system.

The different concrete mixtures were named as follows:

Mix 1 (MPC): Ordinary concrete without slag.

Mix 2 (MGGBFS): Concrete with $30 \%, 40 \%$ or $50 \%$ cement replaced with processed slag.

Mix 3 (MLFS1): Concrete with 30\%, $40 \%$ or $50 \%$ cement replaced with unprocessed slag.

Mix 4 (MLFS2): Concrete with 30\%, 40\% or 50\% cement replaced with stainless steel slag.

Table 2 shows the dosages and the percentages of substitution to be made in each mixture. The W/C (Cement water ratio) (ratio is 0.5; the tests are the continuation of the paper belonging to this research group, in which only substitutions were made up to $25 \%$ [22]. Additional details can be found in that reference. 
Table 2. Concrete mixture proportion.

\begin{tabular}{|c|c|c|c|c|c|c|c|c|c|}
\hline \multirow[b]{2}{*}{ Mix } & \multirow[b]{2}{*}{$\begin{array}{l}\text { Water } \\
(w / b \\
\text { Ratio) }\end{array}$} & \multicolumn{4}{|c|}{ Binder } & \multicolumn{4}{|c|}{ Aggregates } \\
\hline & & Dosage & Cement & Slag & $\begin{array}{l}\text { Additive } \\
\text { (Superpla- } \\
\text { Sticizer) }\end{array}$ & Dosage & $\begin{array}{c}\text { Fine } \\
\text { Sand } \\
0-2 \mathrm{~mm}\end{array}$ & $\begin{array}{c}\text { Sand } \\
0-4 \\
\text { mm }\end{array}$ & $\begin{array}{c}\text { Gravel } \\
4-16 \\
\mathrm{~mm}\end{array}$ \\
\hline MPC & \multirow{10}{*}{0.5} & \multirow{10}{*}{$\begin{array}{c}300 \\
\mathrm{~kg} / \mathrm{m}^{3}\end{array}$} & $100 \%$ & $0 \%$ & \multirow{10}{*}{$3.9 \mathrm{~kg} / \mathrm{m}^{3}$} & \multirow{10}{*}{$\begin{array}{l}2033.8 \\
\mathrm{~kg} / \mathrm{m}^{3}\end{array}$} & \multirow{10}{*}{$15 \%$} & \multirow{10}{*}{$35 \%$} & \multirow{10}{*}{$50 \%$} \\
\hline M30GGBFS & & & $70 \%$ & $30 \%$ & & & & & \\
\hline M40GGBFS & & & $60 \%$ & $40 \%$ & & & & & \\
\hline M50GGBFS & & & $50 \%$ & $50 \%$ & & & & & \\
\hline M30LFS1 & & & $70 \%$ & $30 \%$ & & & & & \\
\hline M40LFS1 & & & $60 \%$ & $40 \%$ & & & & & \\
\hline M50LFS1 & & & $50 \%$ & $50 \%$ & & & & & \\
\hline M30LFS2 & & & $70 \%$ & $30 \%$ & & & & & \\
\hline M40LFS2 & & & $60 \%$ & $40 \%$ & & & & & \\
\hline M50LFS2 & & & $50 \%$ & $50 \%$ & & & & & \\
\hline
\end{tabular}

\section{Tests' Descriptions}

Concrete mixes defined in the preceding section were subject to different tests. The main objective of these tests was to evaluate the effects on the mechanical characteristics (flexural and compressive strength), when cement is replaced by slag.

Concrete was made with the proportions shown in Table 2, where a 30\%, $40 \%$ and $50 \%$ of the PC was substituted by the different slag according to Table 1, providing the different samples previously described.

The different mixture proportion was made according to the EN 12390-2 norm [23] for testing hardened concrete.

\subsection{Physical Properties}

The densities and porosities of the new materials were studied. They were obtained according to the EN 12390-7 norm [24].

A cubic specimen of $10 \mathrm{~cm}$ of edge were used for this test. Two specimens for each type of concrete were tested. The determination of the parameters was made for concrete of more than 28 days of age.

The formulation that was used to obtain the parameters is the following:

$$
\begin{gathered}
\text { Density } \quad \mathrm{D}=\frac{\mathrm{P}_{\mathrm{s}}}{\mathrm{P}_{\mathrm{sss}}-\mathrm{P}_{\text {sum }}} \\
\text { Porosity } \quad \mathrm{P}=100 \frac{\mathrm{P}_{\text {sss }}-\mathrm{P}_{\mathrm{s}}}{\mathrm{P}_{\text {sss }}-\mathrm{P}_{\text {sum }}}
\end{gathered}
$$

The parameters are obtained in the following way:

- Psum: Weight obtained by the hydrostatic balance (submerged weight), placing the specimen inside. This test piece must be completely saturated with water

- $\quad$ Psss (saturated surface dry weight): Obtained by drying the surface water with a damp cloth.

- Ps (dry weight): It is obtained by drying the test pieces in the oven and checking every 24 hours that the mass loss is not less than $0.2 \%$, at a temperature of $105 \pm 5{ }^{\circ} \mathrm{C}$. As indicated in the EN_12390-7 [24] standard, to carry out the test, the hydrostatic balance is used, to which a basket is attached where the test piece is introduced. In that way, one obtains the weight of the submerged sample. 


\subsection{Mechanical Properties}

In order to obtain the compressive strength of the concrete specimens, we used cubes with edges of $10 \mathrm{~cm}$ and an automated press with a $2.000 \mathrm{kN}$ capacity. The specimens were made according to the normative EN 12390-3 [25] and EN 12390-4 [26]; the fresh mixes were vibrated on a vibrating table and they were cured in a water bath $20 \pm 2{ }^{\circ} \mathrm{C}$. Then, they were tested at the ages of $1,7,28$ and 90 days. For each of the mix proportions (Table 2), three different mixtures were made, and two specimens were tested at the different concrete ages (see reference [16] for details).

For the flexural strength, tests prismatic specimens were used with dimensions $4 \times 4 \times 16 \mathrm{~cm}^{3}$, made of the same kneaded as for the rest of the trial. That parameter was calculated using the uniform application of centred load. The same type of curing as the compressive test specimens was applied. This test was performed at 28 and 90 days. The prismatic test specimen was subjected to a bending moment by applying a load through upper and lower rollers, registering the maximum applied load calculating the flexural strength by EN-12390-5 [27]

\subsection{Leachate}

Finally, the mixtures are subjected to leachate tests. The cement substitution percentage chosen was $30 \%$ for every mixture. Additionally, we carried the test out using a $50 \%$ slag substitution percentage for GGBFS, since throughout the research, it showed similar behaviour to conventional concrete. Specimens were immersed in 1 litre of distilled water for 2 days. The treatment that was made to the water sample in the laboratory was to sieve the sample with a $0.45 \mu \mathrm{m}$ filter, and acidify them to $\mathrm{pH}<2$. Once that process was done, it was introduced into the spectrometer.

\section{Results and Discussion}

The results obtained for the physical (density and porosity), mechanical (compressive and flexural) and environmental (leachate) tests for each of the mixtures and their different substitutions are shown below, making a comparison between the percentages of loss and gains of strength, and the differences between the varieties.

\subsection{Density}

In the differently manufactured mixtures, it was observed (Table 3) that the density varied very little with respect to the standard mixture, decreasing only in the mixtures made with the slag LFS1; therefore, this indicates that LFS1 aerates the mixture more. It was significant, and the porosity of the material also increased significantly. For the mixtures with the other two types of slags, there were no significant differences; therefore, replacing them in the mixtures would not pose any problem for this property.

Table 3. Density of the mixtures.

\begin{tabular}{|c|c|c|c|c|}
\hline \multicolumn{5}{|c|}{ Density $\left(\mathrm{kg} / \mathrm{m}^{3}\right)$} \\
\hline & PC & GGBFS & LFS1 & LFS2 \\
\hline $30 \%$ & $2500 \pm 100$ & $2490 \pm 100$ & $2450 \pm 50$ & $2530 \pm 10$ \\
\hline $40 \%$ & $2500 \pm 100$ & $2490 \pm 100$ & $2370 \pm 30$ & $2510 \pm 10$ \\
\hline $50 \%$ & $2500 \pm 100$ & $2490 \pm 100$ & $2370 \pm 40$ & $2510 \pm 10$ \\
\hline
\end{tabular}

\subsection{Porosity}

The results of the porosity test are shown in the Table 4 and plotted in Figure 2. 
Table 4. Porosity of the mixtures.

\begin{tabular}{|c|c|c|c|c|}
\hline \multicolumn{5}{|c|}{ Porosity (\%) } \\
\hline & PC & GGBFS & LFS1 & LFS2 \\
\hline $0 \%$ & $1.81 \pm 0.5$ & - & - & - \\
\hline $30 \%$ & - & $1.51 \pm 0.2$ & $4.01 \pm 0.5$ & $0.91 \pm 0.1$ \\
\hline $40 \%$ & - & $1.27 \pm 0.2$ & $6.1 \pm 0.5$ & $0.78 \pm 0.1$ \\
\hline $50 \%$ & - & $1.53 \pm 0.2$ & $6.60 \pm 0.5$ & - \\
\hline
\end{tabular}

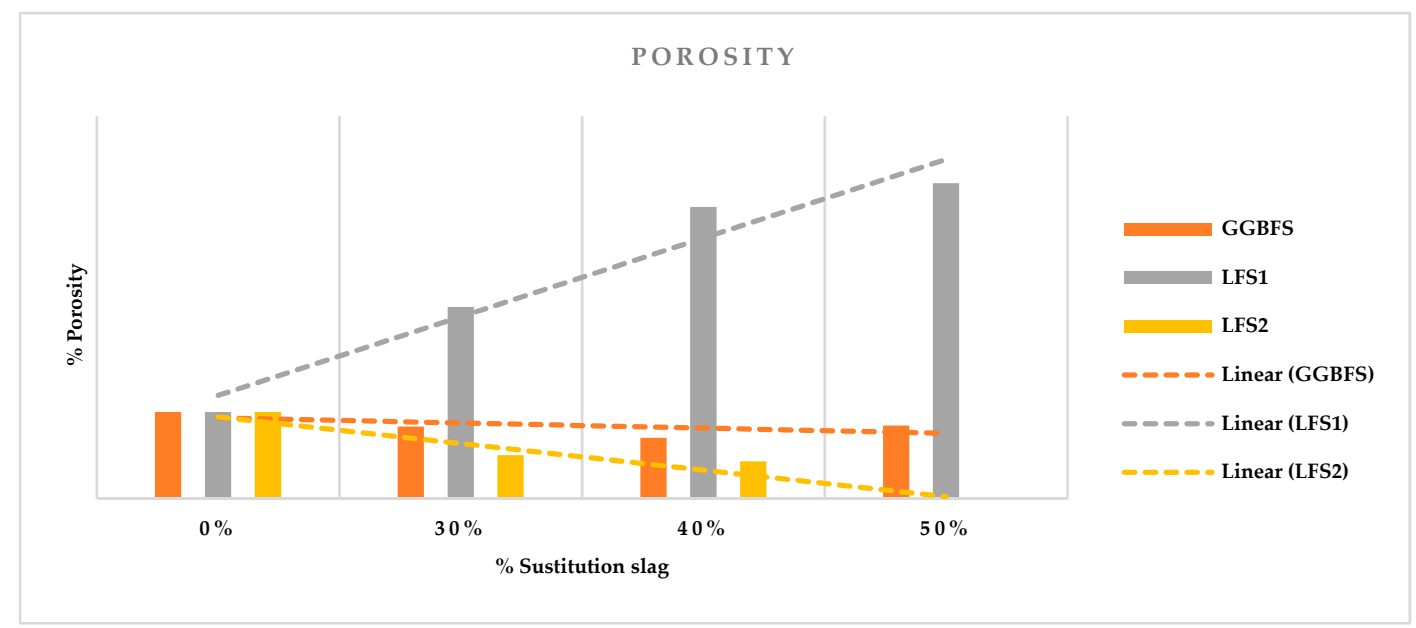

Figure 2. Porosity.

This property is tightly linked to the durability of the concrete. Taking as reference the PC mixture, for the mixtures with GGBFS, we see that it is practically constant for all the substitutions, even decreasing its porosity by $25 \%$ in the $50 \%$ substitution, with respect to conventional concrete. Regardless of the percentages of cement substitution, it was observed that the mixtures with slag LFS1 had a high porosity, since its porosity increased significantly. We saw in point Section 4.1, that for the mixture LFS1, the porosity increased up to $60 \%$, so it was confirmed that this type of slag increases the incorporation of air into the concrete. On the contrary, it is observed that those made with slag LFS2, obtained a lower porosity, reaching up to a $43 \%$ improvement of results with respect to conventional concrete; this indicates that the links between particles that occur within the mixture are greater with this type of slag, without increasing its density by the same percentage; therefore, they provide better mixing conditions at the time of commissioning.

In short, the GGBFS and LFS2 mixtures' lower porosity means a better performance in the long run, as this makes it more difficult for external agents to lead to the deterioration of the material, which affects the steel frame, in the case of reinforced elements. The opposite occurs with the LFS1 mixtures; it has a higher porosity, which can lead to the material having a shorter shelf life thanks to external agents that can damage it.

\subsection{Compressive Strength}

Results of mixtures for slag substitution.

\subsubsection{Slag GGBF}

Figure 3 shows the compressive strength over time and how the GGBF slag influences concrete properties, from 1 day to 90 days of testing. These data are mean values for six samples per test (for the different concrete age). Results show that the compressive strength in the first days of hardening was lower than in conventional mixtures, becoming equal after 7 days and even increasing after 
30 days. This is coincident with our previous results [16] and in accordance with the results reported by Wang [28,29].

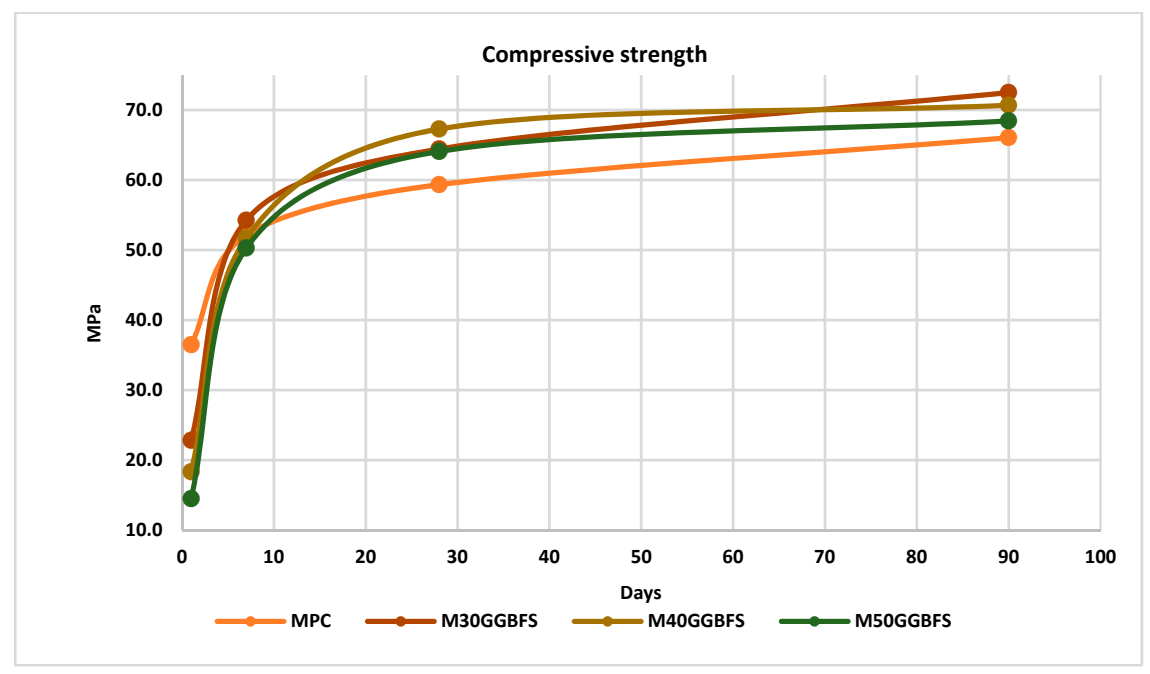

Figure 3. Compressive strength GGBFS.

Figure 4 shows the percentages of loss or increase in strength at day one and after 90 days. It is easy to visualize how, at one day there was up to $50 \%$ less strength than the conventional mixture. Nevertheless, after 90 days, it acquired up to $10 \%$ more compressive strength in the $30 \%$ replacement.

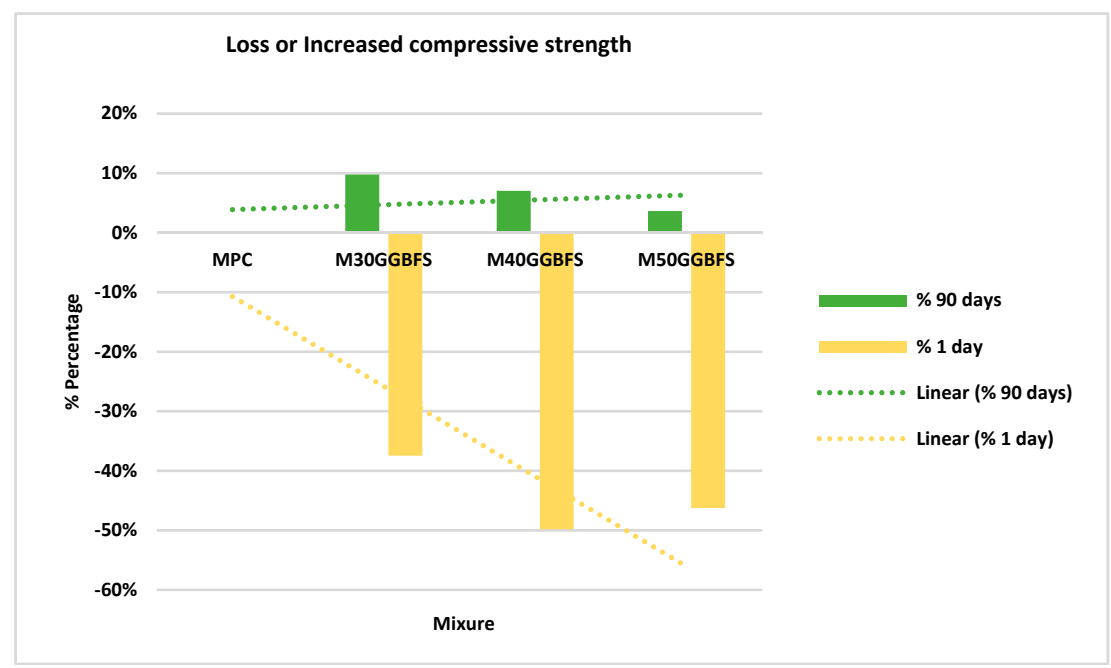

Figure 4. Percentage of loss or increase in compressive strength GGBFS.

\subsubsection{Slag LFS1}

Figure 5 shows the mean values obtained for the samples made with slag LFS1. This average has been made with six test specimens for each of the four mixtures. 


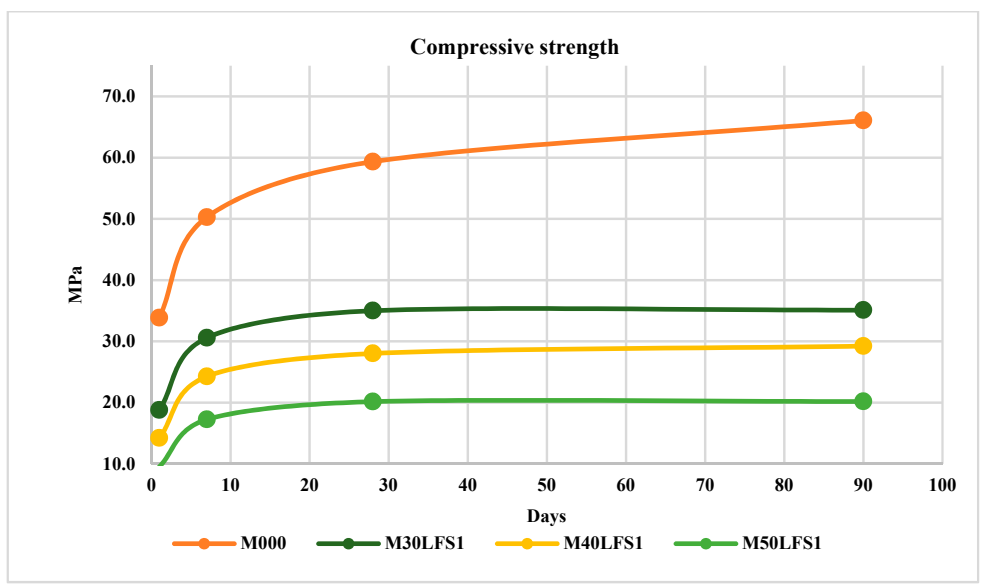

Figure 5. Compressive strength LFS1.

The results show that in the LFS1 slag there was a lesser strength for day one, but in this case the compressive strength decreased over time. The loss at 90 days with a $50 \%$ substitution of cement was of almost $70 \%$ of PC's strength, as shown in Figure 6. The loss of strength is maintained at both day one and after 90 days.

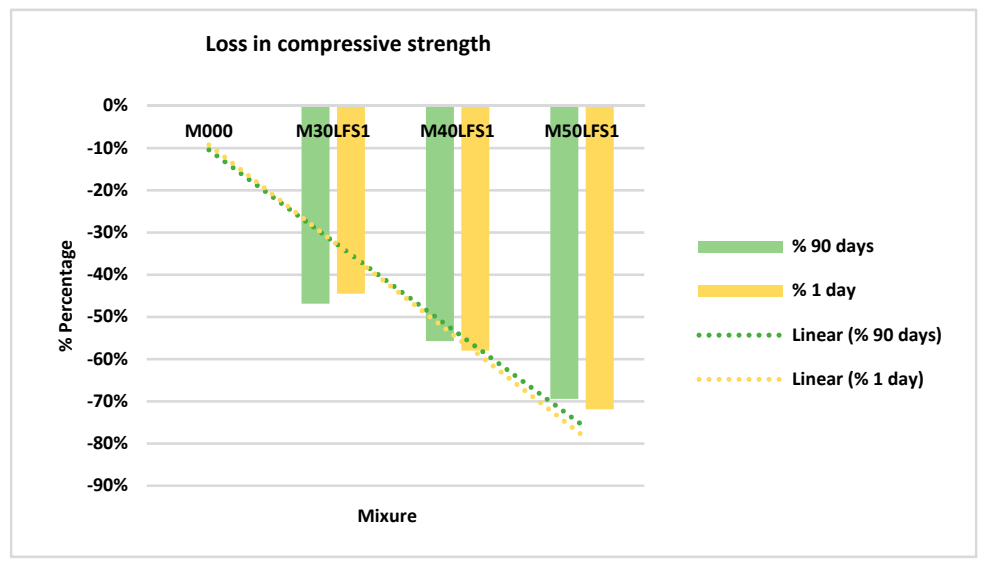

Figure 6. Percentage of loss in compressive strength LFS1.

\subsubsection{Slag LFS2}

Figure 7 shows the mean values for the specimens made of slag LFS2. Again, six specimens per mixture and age were tested.

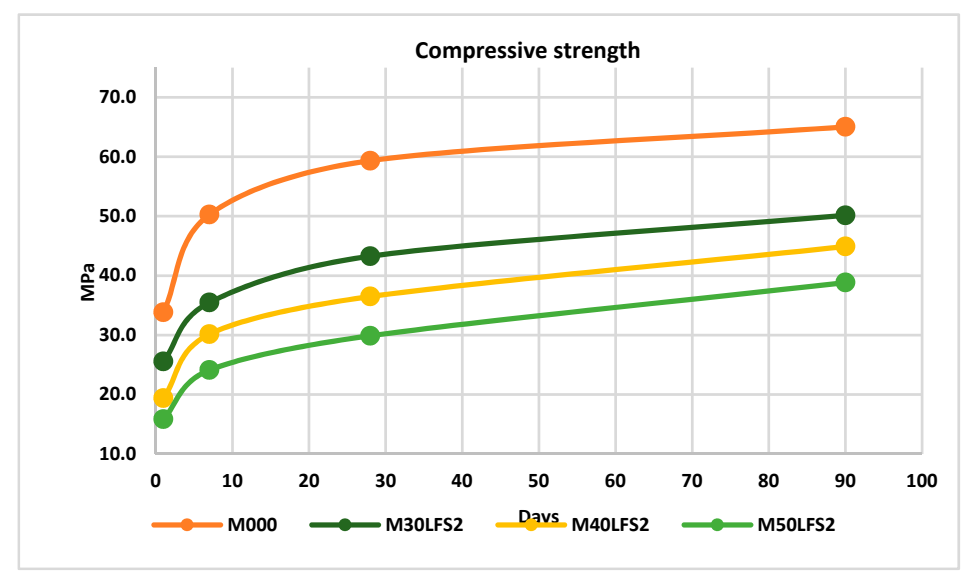

Figure 7. Compressive strength LFS2. 
With the slag LFS2, it was observed, as in the mixtures with slag LFS1, that there was a decrease of the strength both on day one, and over time. At 90 days and with a 50\% replacement of cement, the loss was $40 \%$ (Figure 8 ).

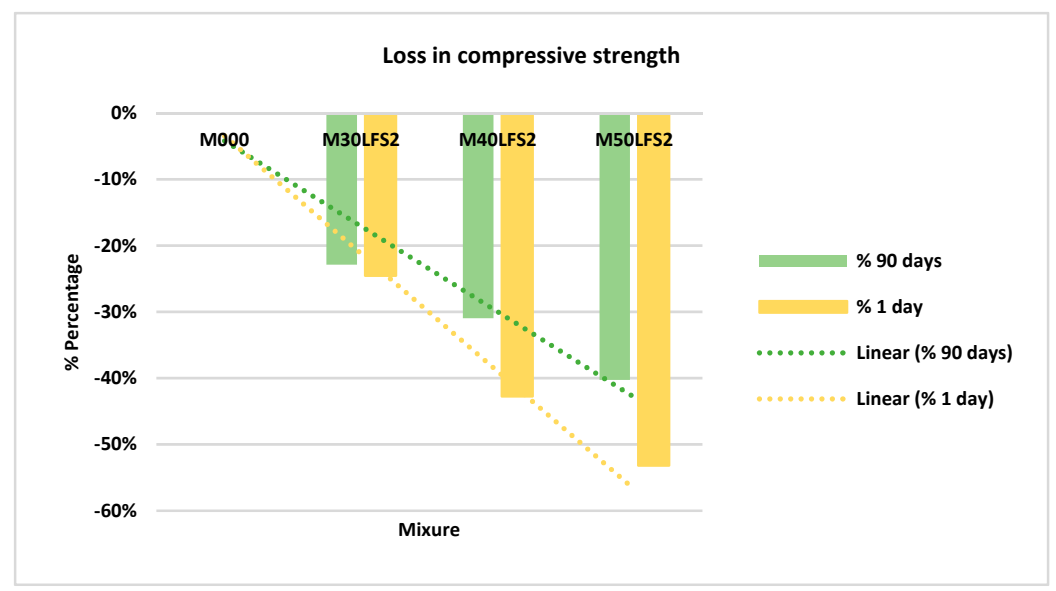

Figure 8. Percentage of loss in compressive strength LFS2.

The results lead us to think that, for high percentage substitutions, specimens with ladle furnace slag (LFS) substitutions have a higher strength loss compared with conventional concrete than those with blast furnace slag (GGBFS) substitutions. Particularly, the mixtures with LFS1 substitutions showed the worst behaviour at compressive strength tests, obtaining up to a $70 \%$ of compressive strength loss, when the cement substitution percentage was $50 \%$.

\subsubsection{Comparison between the Mixtures}

In Figure 9, the comparison of compressive strength for 90 day is shown for the different mixtures. In order to complete the figure, results previously reported with a $25 \%$ cement replacement [16] have also been included in the Figure.

It is observed how GGBFS slag presents an increase in strength; it provides pozzolanic benefits to the mixture. On the contrary, what occurs in those made with LFS slags has already been observed by other researchers, like Manso [30,31]. In this figure, it can be seen that the proportion of loss of strength is not the same in the two cases being the substitution up to $30 \%$ of LFS2 admissible for concretes with minor strength needs.

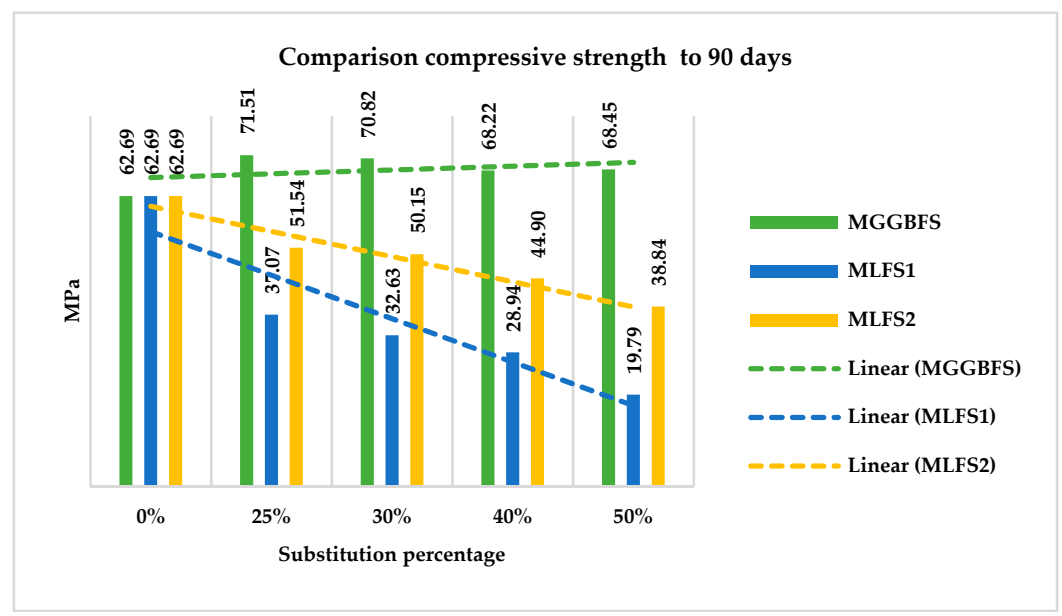

Figure 9. Comparison compressive strength to 90 days, for the three different slag. 
We can conclude that the blast furnace slag (GGBFS) is a good substitute for cement in terms of compressive strength. On the other hand, there is such a loss of strength on the other two ladle furnace slags (in the best of cases, $23 \%$ ), that rule out any possibility of using this concrete as structural material. Nevertheless, they could be acceptable, being able to withstand medium-environmental pressure for situations in which the strength needs are lesser.

Returning to the ternary diagram in Figure 1 , it is clear that a higher amount of $\mathrm{SiO}_{2}$, means better pozzolanic characteristics in the mixture, and in this case, it was observed that the mixtures with slag LFS1 were those that obtained the worst compressive strength, a cause not only of the greater porosity, and therefore greater amount of voids that weaken the mixture, but the slag also contained less $\mathrm{SiO}_{2}$.

\subsection{Flexure Strength Tests}

A similar study has been made to evaluate the flexure strength. In this case, the results obtained for all the mixtures are shown in Figures 10 and 11, breaking the test pieces at 28 and 90 days, respectively.

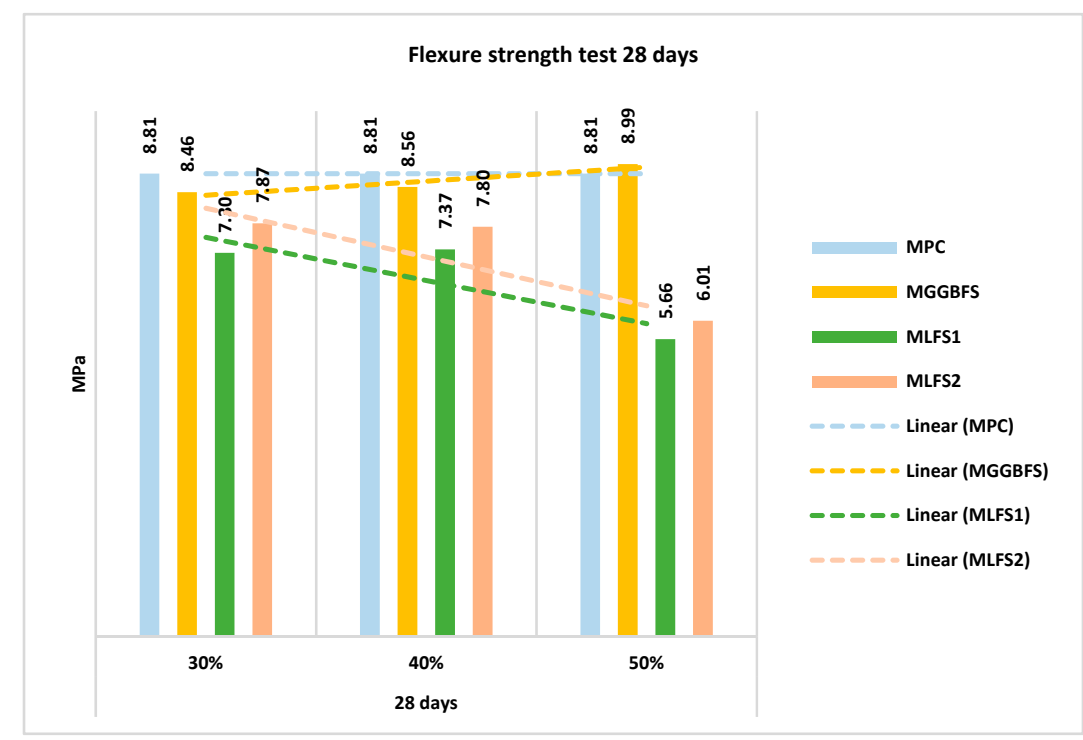

Figure 10. Flexure strength test 28 Days.

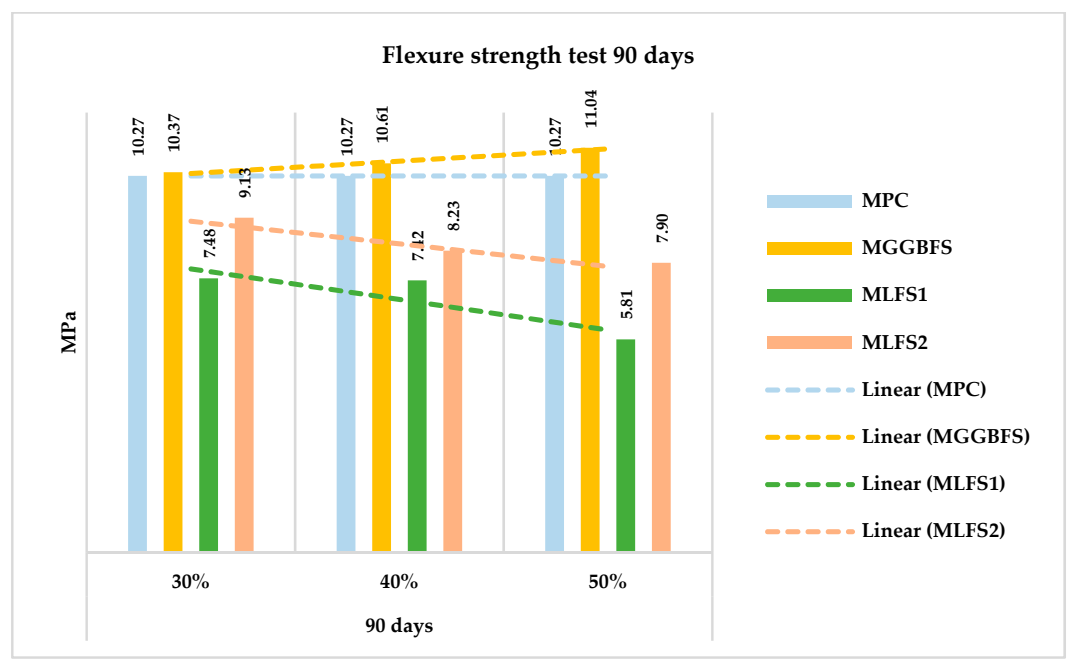

Figure 11. Flexure strength test at 90 days.

Following a similar trend to the previous section, the mixtures made with ladle furnace slag (LFS) obtained worse strength than the mixture without substitution. On the contrary, those made with blast furnace slag (GGBFS) were equal to and even improved the reference concrete. 
This loss or increase in strength was observed not only at 28 days, but also at 90 days (Figure 10). It also shows that mixtures with substitutions LFS1 behave worse than LFS2; additionally, showing clear differences between them. This behaviour is due to the chemical composition of the slag.

The percentages of loss of flexure strength of each one of the cases are shown in Figure 12, where it is seen how the GGBFS contributes to the material, the same characteristics as the PC, increasing its strength by $4 \%$ with a substitution of $50 \%$.

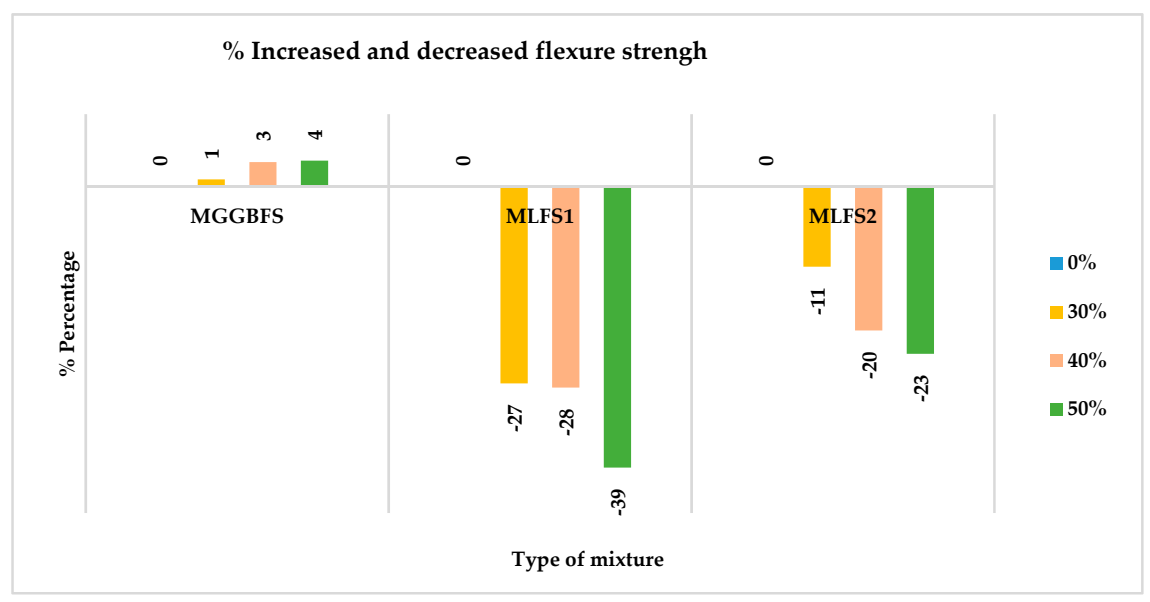

Figure 12. Percentage increased and decreased flexure strength.

\subsection{Comparison between 90-Day Flexure and Compressive Strength}

The significance of this study is highlighted in the comparison of the gain or loss of the strength against flexure and compression combined. We will focus on that point in this section.

In Figure 13, the comparison in percentage of the strength, both compressive and flexural, in each of the mixtures made, highlights that the losses of flexural strength of the mixtures with slag LFS are much lower than those of compressive strength. This decrease in strength is practically half in most cases. In the strength of the mixtures with GGBFS does not increase twice as much in the flexural strength, as would be expected by the previous results, but only half. Apart from substitutions of $50 \%$, this percentage of $4 \%$ is maintained.

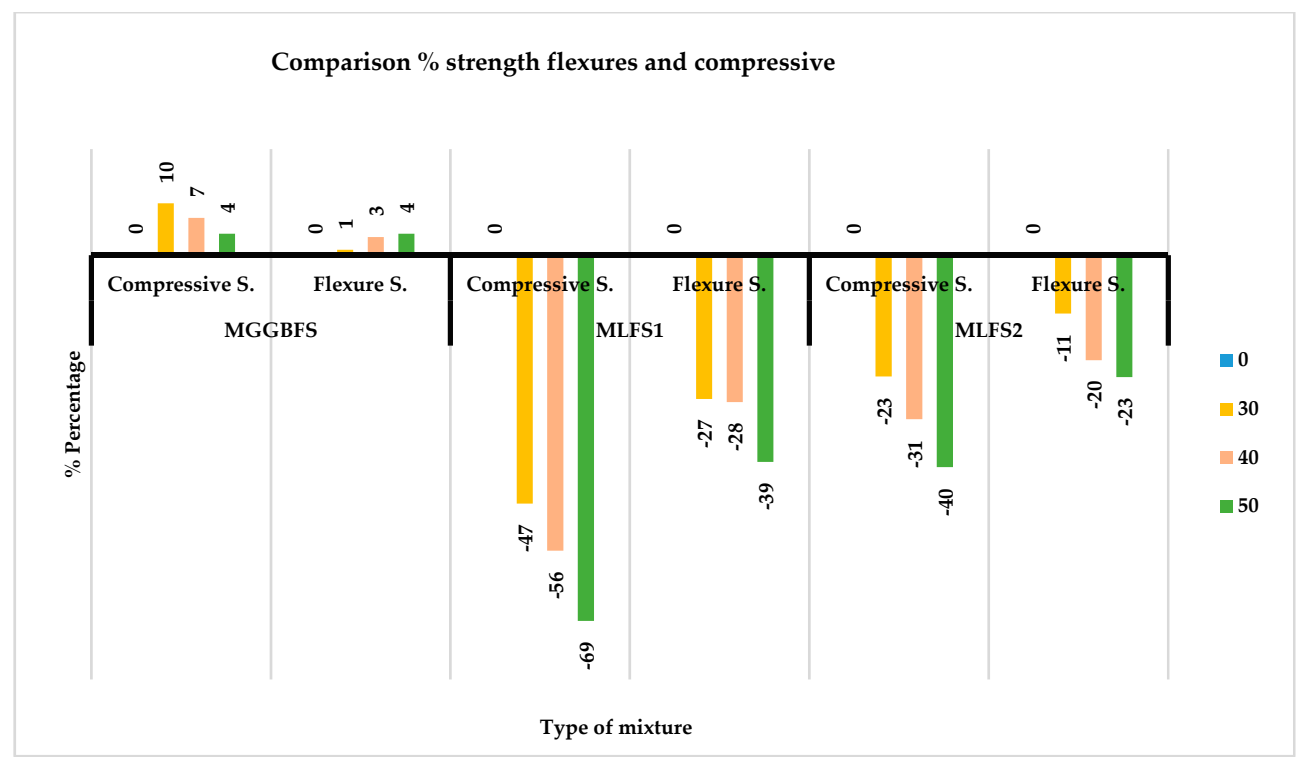

Figure 13. Comparison of flexural and compressive strength. 
This indicates the feasibility of LFS slag in non-structural elements, valuing a waste as a by-product, reducing the production of cement that generates a large amount of $\mathrm{CO}_{2}$ into the environment.

In all the investigations where the laws of mechanical behaviour (constitutive models) for materials are established, outcomes are considered a representative volumetric element of the same. It is assumed that the material behaves as a continuous medium; that is, it has the same elastic properties at each point.

\subsection{Leachate}

The results obtained are shown in Table 5.

Table 5. Leachate of the mixtures.

\begin{tabular}{ccccccc}
\hline $\begin{array}{c}\text { Chemical } \\
\text { Element }\end{array}$ & PC & $\begin{array}{c}\text { GGBFS } \\
\mathbf{( 3 0 \% )}\end{array}$ & $\begin{array}{c}\text { GGBFS } \\
\mathbf{( 5 0 \% )}\end{array}$ & LFS1 (30\%) & LFS2 (30\%) & $\begin{array}{c}\text { CFR 40/261.24 } \\
(\mathbf{m g} / \mathbf{L})\end{array}$ \\
\hline$[\mathrm{Mg}] \mu \mathrm{g} / \mathrm{L}$ & $20.2 \pm 1.0$ & $21.3 \pm 0.2$ & $28.1 \pm 1.0$ & $26.0 \pm 1.2$ & $31.3 \pm 1.0$ & - \\
\hline$[\mathrm{Si}] \mu \mathrm{g} / \mathrm{L}$ & $8.60 \pm 0.33$ & $13.1 \pm 1.0$ & $13.3 \pm 1$ & $9.30 \pm 0.40$ & $7.90 \pm 0.73$ & - \\
\hline$[\mathrm{Ti}] \mu \mathrm{g} / \mathrm{L}$ & $<0.100$ & $<0.100$ & $<0.100$ & $<.0,100$ & $<0.100$ & - \\
\hline$[\mathrm{Cr}$ total $] \mu \mathrm{g} / \mathrm{L}$ & $15.6 \pm 0.6$ & $1.10 \pm 0.05$ & $0.394 \pm 0.013$ & $0.673 \pm 0.040$ & $0.162 \pm 0.023$ & 5 \\
\hline$[\mathrm{Mn}] \mu \mathrm{g} / \mathrm{L}$ & $0.100 \pm 0.010$ & $0.180 \pm 0.010$ & $0.190 \pm 0.04$ & $0.150 \pm 0.020$ & $0.101 \pm 0.01$ & - \\
\hline$[\mathrm{Fe}] \mu \mathrm{g} / \mathrm{L}$ & $18.2 \pm 0.7$ & $17.0 \pm 0.2$ & $10.6 \pm 0.03$ & $1.82 \pm 0.03$ & $8.23 \pm 0.20$ & - \\
\hline$[\mathrm{Ni}] \mu \mathrm{g} / \mathrm{L}$ & $0.270 \pm 0.030$ & $0.510 \pm 0.020$ & $0.280 \pm 0.012$ & $0.150 \pm 0.013$ & $0.270 \pm 0.021$ & - \\
\hline$[\mathrm{Cu}] \mu \mathrm{g} / \mathrm{L}$ & $1.92 \pm 0.10$ & $4.3 \pm 0.36$ & $8.80 \pm 0.033$ & $1.50 \pm 0.03$ & $4.00 \pm 0.04$ & - \\
\hline$[\mathrm{Zn}] \mu \mathrm{g} / \mathrm{L}$ & $6.60 \pm 0.20$ & $6.10 \pm 0.12$ & $3.90 \pm 0.20$ & $2.92 \pm 0.10$ & $4.40 \pm 0.14$ & - \\
\hline$[\mathrm{As}] \mu \mathrm{g} / \mathrm{L}$ & $<0.200$ & $<0.200$ & $<0.200$ & $<0.200$ & $<0.200$ & 5 \\
\hline$[\mathrm{Cd}] \mu \mathrm{g} / \mathrm{L}$ & $<0.100$ & $<0.100$ & $<0.100$ & $<0.100$ & $<0.100$ & 1 \\
\hline$[\mathrm{Sn}] \mu \mathrm{g} / \mathrm{L}$ & $<0.100$ & $<0.100$ & $<0.100$ & $<0.100$ & $<0.100$ & - \\
\hline$[\mathrm{Pb}] \mu \mathrm{g} / \mathrm{L}$ & $0.543 \pm 0.022$ & $2.02 \pm 0.02$ & $0.230 \pm 0.010$ & $0.190 \pm 0.001$ & $0.333 \pm 0.002$ & - \\
\hline
\end{tabular}

In general terms, it can be observed how most of the values obtained had a decrease in relation to conventional concrete. The most significant is to see how the amount of chromium in the mixtures with slag, compared with the conventional concrete mixture, decreased.

It is significant how one of the most harmful elements in the leachate is chromium, and this element decreases with respect to the master mix. This is interpreted as the encapsulation of the slag being diluted into the cementitious matrix absorbing this metal, without generating any environmental danger when it is used.

There are some values which are slightly above those obtained with the reference concrete (PC); however, all these leachate ranges fall within the values allowed by the Code of Federal Regulations (CFR) 40CFR/261.24.

According to those maximum values the encapsulation of the slag in the concrete not only does not leach contaminant, but also reduces the leachate of one of the more dangerous components that are measured in the CFR - the $\mathrm{Cr}$, not exceeding the limit of $5 \mathrm{mg} / \mathrm{L}$.

\section{Conclusions}

According to the results described, we can outline the following conclusions:

$\rightarrow$ The results lead us to think that, for high percentage substitutions, specimens with ladle furnace slag (LFS) substitutions have a higher strength loss compared with conventional concrete than those with blast furnace slag (GGBFS) substitutions. Particularly, the mixture with LFS1 slag substitutions showed the worst behaviour in compressive strength tests, obtaining up to a $72 \%$ of compressive strength loss with a cement substitution percentage of $50 \%$.

$\rightarrow$ On the other hand, specimens with blast furnace slag substitution showed an increase in compressive strength of $10 \%$ at 90 days. Mixtures using this type of slag substitution showed 
a slower hardening process, with a compressive strength reduction at day one, but gaining a compressive strength similar to or even above the conventional concrete after 7 days.

$\rightarrow \quad$ The chemical characteristics of the slag influence the mixtures and strength. It was observed in this study, that for essential components such as $\mathrm{SiO}_{2}$, the lower the percentage, the lower the strength. As it can be seen in the mixes made with LFS1 and LFS2 slags, the lack of that compound makes them work worse. GGBFSs are the best performers, having twice the amount of that compound, increasing its strength even with respect to conventional concrete. The good pozzolanic activity that contributes to those types of cementitious mixtures was verified.

$\rightarrow$ Another characteristic result of this investigation is the difference of compressive and flexural strength among the different mixtures. LFS presents a loss of flexural strength that is the half of the loss of compressive strength. This suggests that they could be used in other fields of civil engineering with lower strength requirements.

$\rightarrow$ Leaching test confirmed that slag does not cause damage to the environment. The results of the leaching tests of concrete mixtures with slag are similar to the results of traditional concrete. Therefore, slag encapsulation into the concrete seems to be a good strategy to manage this waste product, instead of it being deposited in landfills where it will pollute the environment by leaching.

As a final conclusion, it is clear that blast furnace slag (GGBFS) is suitable for the production of a sustainable concrete, and as a substitute for cement, since it has been proven to bring the same characteristics to the mixture as cement.

For the other two types of mixtures with slag (LFS), a non-structural application would be suitable. This would put a value on the residue, avoiding the consumption of raw material and reducing the landfill deposit.

Concrete production with slag is a clear example of circular economics, since the steel manufactured, necessary to build structures, generates waste that can be incorporated to the same building cycle.

Author Contributions: M.E.P.-R., F.P.-G., A.G.-H., M.J.O. and M.D.R.-C. conceived and designed the experiments; M.E.P.-R., M.D.R.-C. and F.P.-G. performed the experiments and analysed the data; and M.E.P.-R. and A.G.-H. wrote the paper.

Funding: The authors acknowledge the financial support provided to this work by the Center of Industrial Technological Development (CDTI) of the Ministry of Economy and Competitiveness as a part of the research project IDI-20160509, through the companies DRACE and GEOCISA.

Conflicts of Interest: The authors declare no conflict of interest.

\section{References}

1. Manso, J.M.; Polanco, J.A.; Losañez, M.; González, J.J. Durability of concrete made with EAF slag as aggregate. Cem. Concr. Compos. 2006, 28, 528-534. [CrossRef]

2. González, J.S.; Gayarre, F.L.; Pérez, C.L.-C.; Ros, P.S.; López, M.A.S. Influence of recycled brick aggregates on properties of structural concrete for manufacturing precast prestressed beams. Constr. Build. Mater. 2017, 149, 507-514. [CrossRef]

3. New Views on Effect of Recycled Aggregates on Concrete Compressive Strength. ACI Mater. J. 2013, 110, 687-696.

4. Tsakiridis, P.; Papadimitriou, G.; Tsivilis, S.; Koroneos, C.; Tsakiridis, P. Utilization of steel slag for Portland cement clinker production. J. Hazard. Mater. 2008, 152, 805-811. [CrossRef] [PubMed]

5. Çelik, E.; Nalbantoglu, Z. Effects of ground granulated blastfurnace slag (GGBS) on the swelling properties of lime-stabilized sulfate-bearing soils. Eng. Geol. 2013, 163, 20-25. [CrossRef]

6. Shi, C.; Hu, S. Cementitious properties of ladle slag fines under autoclave curing conditions. Cem. Concr. Res. 2003, 33, 1851-1856. [CrossRef]

7. Pellegrino, C.; Cavagnis, P.; Faleschini, F.; Brunelli, K. Properties of concretes with Black/Oxidizing Electric Arc Furnace slag aggregate. Cem. Concr. Compos. 2013, 37, 232-240. [CrossRef] 
8. Vijayaraghavan, J.; Jude, A.B.; Thivya, J. Effect of copper slag, iron slag and recycled concrete aggregate on the mechanical properties of concrete. Resour. Policy 2017, 53, 219-225. [CrossRef]

9. Adegoloye, G.; Beaucour, A.-L.; Ortola, S.; Noumowe, A. Concretes made of EAF slag and AOD slag aggregates from stainless steel process: Mechanical properties and durability. Constr. Build. Mater. 2015, 76, 313-321. [CrossRef]

10. Al-Jabri, K.S.; Hisada, M.; Al-Saidy, A.H.; Al-Oraimi, S. Performance of high strength concrete made with copper slag as a fine aggregate. Constr. Build. Mater. 2009, 23, 2132-2140. [CrossRef]

11. Al-Jabri, K.; Taha, R.; Al-Hashmi, A.; Al-Harthy, A. Effect of copper slag and cement by-pass dust addition on mechanical properties of concrete. Constr. Build. Mater. 2006, 20, 322-331. [CrossRef]

12. Rubio-Cintas, M.; Barnett, S.; Perez-García, F.; Parron-Rubio, M. Mechanical-strength characteristics of concrete made with stainless steel industry wastes as binders. Constr. Build. Mater. 2019, 204, 675-683. [CrossRef]

13. López Boadella, Í.; López Gayarre, F.; Suárez González, J.; Gómez-Soberón, J.; López-Colina Pérez, C.; Serrano López, M.; de Brito, J.; López Boadella, Í.; López Gayarre, F.; Suárez González, J.; et al. The Influence of Granite Cutting Waste on The Properties of Ultra-High Performance Concrete. Materials 2019, 12, 634. [CrossRef] [PubMed]

14. Juan-Valdés, A.; García-González, J.; Rodríguez-Robles, D.; Guerra-Romero, M.; López Gayarre, F.; De Belie, N.; Morán-del Pozo, J.; Juan-Valdés, A.; García-González, J.; Rodríguez-Robles, D.; et al. Paving with Precast Concrete Made with Recycled Mixed Ceramic Aggregates: A Viable Technical Option for the Valorization of Construction and Demolition Wastes (CDW). Materials 2018, 12, 24. [CrossRef] [PubMed]

15. Panda, B.; Paul, S.C.; Hui, L.J.; Tay, Y.W.D.; Tan, M.J. Additive manufacturing of geopolymer for sustainable built environment. J. Clean. Prod. 2017, 167, 281-288. [CrossRef]

16. Amario, M.; Pepe, M.; Martinelli, E.; Filho, R.D.T. Rheological Behavior at Fresh State of Structural Recycled Aggregate Concrete. In Proceedings of the fib symposium 2017, Maastricht, The Netherlands, 12-14 June 2017; pp. 215-223.

17. Öner, A.; Akyuz, S. An experimental study on optimum usage of GGBS for the compressive strength of concrete. Cem. Concr. Compos. 2007, 29, 505-514. [CrossRef]

18. Wang, H.; Sun, X.; Wang, J.; Monteiro, P.J. Permeability of Concrete with Recycled Concrete Aggregate and Pozzolanic Materials under Stress. Materials 2016, 9, 252. [CrossRef]

19. Pal, S.; Mukherjee, A.; Pathak, S. Investigation of hydraulic activity of ground granulated blast furnace slag in concrete. Cem. Concr. Res. 2003, 33, 1481-1486. [CrossRef]

20. Perez-Garcia, F.; Parron-Rubio, M.E.; Garcia-Manrique, J.M.; Rubio-Cintas, M.D. Study of the Suitability of Different Types of Slag and Its Influence on the Quality of Green Grouts Obtained by Partial Replacement of Cement. Materials 2019, 12, 1166. [CrossRef]

21. Khatib, J.; Hibbert, J.; Khatib, J. Selected engineering properties of concrete incorporating slag and metakaolin. Constr. Build. Mater. 2005, 19, 460-472. [CrossRef]

22. Parron-Rubio, M.E.; Pérez-García, F.; Gonzalez-Herrera, A.; Rubio-Cintas, M.D. Concrete Properties Comparison When Substituting a 25\% Cement with Slag from Different Provenances. Materials 2018, 11, 1029. [CrossRef] [PubMed]

23. Testing Hardened Concrete_Part 2: Making and Curing Specimens for Strength Tests; EN 12390-2: 2009; European Committee for Standardization: Brussels, Belgium, 2009.

24. Testing Hardened Concrete. Density of Hardened Concrete; EN 12390-7:2009; European Committee for Standardization: Brussels, Belgium, 2009.

25. Testing Hardened Concrete. Part 3: Compressive Strength of Test Specimens; EN 12390-3: 2001; European Committee for Standardization: Brussels, Belgium, 2001.

26. Testing of Hardened Concrete. Part 4: Compressive Strength Specification for Testing Machines; EN 12390-4: 2009; European Committee for Standardization: Brussels, Belgium, 2009.

27. Testing Hardened Concrete. Part 5: Flexural Strength of Test Specimens; EN 12390-5:2009; European Committee for Standardization: Brussels, Belgium, 2009.

28. Wang, Q.; Yan, P.; Mi, G. Effect of blended steel slag-GBFS mineral admixture on hydration and strength of cement. Constr. Build. Mater. 2012, 35, 8-14. [CrossRef]

29. Wang, Q.; Yang, J.; Yan, P. Cementitious properties of super-fine steel slag. Powder Technol. 2013, 245, 35-39. [CrossRef] 
30. Rodriguez, Á.; Manso, J.M.; Aragón, Á.; Gonzalez, J.J. Strength and workability of masonry mortars manufactured with ladle furnace slag. Resour. Conserv. Recycl. 2009, 53, 645-651.

31. Manso, J.M.; Ortega-López, V.; Polanco, J.A.; Setién, J. The use of ladle furnace slag in soil stabilization. Constr. Build. Mater. 2013, 40,126-134. [CrossRef]

(C) 2019 by the authors. Licensee MDPI, Basel, Switzerland. This article is an open access article distributed under the terms and conditions of the Creative Commons Attribution (CC BY) license (http://creativecommons.org/licenses/by/4.0/). 